\title{
Cost-Effectiveness of Telemedicine in Asia: A Scoping Review
}

\author{
Aisha Salsabilla $\mathbb{D}^{\prime}$ \\ Alifia B Azzahra (D) \\ Raden IP Syafitri (D) \\ Woro Supadmi \\ Auliya A Suwantika (D) ${ }^{1,3,4}$ \\ 'Department of Pharmacology and \\ Clinical Pharmacy, Faculty of Pharmacy, \\ Universitas Padjadjaran, Bandung, \\ Indonesia; ${ }^{2}$ Faculty of Pharmacy, \\ Universitas Ahmad Dahlan, Yogyakarta, \\ Indonesia; ${ }^{3}$ Center of Excellence in \\ Higher Education for Pharmaceutical \\ Care Innovation, Universitas Padjadjaran, \\ Bandung, Indonesia; ${ }^{4}$ Center for Health \\ Technology Assessment, Universitas \\ Padjadjaran, Bandung, Indonesia
}

Correspondence: Auliya A Suwantika

Department of Pharmacology and Clinical

Pharmacy, Faculty of Pharmacy,

Universitas Padjadjaran, Bandung,

Indonesia

Email auliya@unpad.ac.id
Background: In the area where there is a lack of medical experts, telemedicine gives a lot of benefits to deal with the distance and limited public infrastructure.

Objective: This study aimed to review the literature on the cost-effectiveness of telemedicine in Asian countries and possibly to provide recommendations on implementing telemedicine in this region.

Methods: Articles were independently screened in two selected databases (PubMed and EBSCO). The framework of patient, intervention, comparison, and outcome (PICO) was applied by considering Asian population, the intervention of telemedicine, current situation (without telemedicine) as the comparator, and cost per QALY gained as the major outcome. Results: A total of 870 articles were identified from two databases: PubMed ( $n=689$ articles) and EBSCO ( $\mathrm{n}=181$ articles). After removing 181 duplicates, 689 articles were screened by title and abstract, excluding 665 records. After the full-text screening on 24 articles, 8 articles were selected for further analysis. Various perspectives were applied in the included studies, such as societal, healthcare, and program perspectives. All studies applied different time horizons, such as 3-month, 25-year, 40-year, and lifetime. Among all included studies, several studies applied mathematical modeling.

Conclusion: The implementation of telemedicine in Asia can be a promising intervention since it can enhance the effectiveness of health services by saving time and travel costs. It also can reduce the overall costs of treatment, improve patients' quality of life, and expand access to essential health services.

Keywords: cost per QALY gained, economic evaluation studies, cost utility analysis, costeffective, cost saving

\section{Introduction}

Over the last decade, the use of telemedicine has improved patients' health because both of patients and physicians are able to interact two ways and real-time via the internet. ${ }^{1}$ The main objective of telemedicine is to provide equal access of healthcare to the users. In the area where there is a lack of medical experts, telemedicine gives a lot of benefits to deal with the distance and limited public infrastructure. In particular, it is also beneficial for mitigating crises or emergencies, including for mitigating the pandemic of coronavirus disease 2019 (COVID-19). It can provide information about the treatment of COVID-19 that can be accessed quickly and easily, as reported in Singapore. ${ }^{2}$ In particular, its services have been rising in some countries in Asia, according to a previous study by Suzuki et al in $2016 .^{3}$ Because of the internet penetration and the shortage of physicians, the use of telemedicine in Thailand and Indonesia has been increasing significantly. ${ }^{3}$ 
Despite the fact that telemedicine offers a lot of advantages, its services have not been fully integrated into the national healthcare systems. ${ }^{2}$ The progress of this integration was reported to be very slow, specifically in Asian countries. ${ }^{4}$ This situation might be caused by several complicated factors. ${ }^{5,6}$ A limited number of trainings for clinicians to implement telemedicine also contribute to the barriers that still exist in the national healthcare system. ${ }^{7}$ To deal with this situation, economic evaluations of telemedicine in Asia are required to be implemented. ${ }^{8}$ As a healthcare intervention, quality-adjusted life years (QALYs) can be measured as the final outcome of this intervention by taking this parameter and relevant costs into account in the studies. ${ }^{9}$ This study aimed to review the literature on the cost-effectiveness of telemedicine in Asian countries and possibly to provide recommendations on implementing telemedicine in this region.

\section{Methods}

Articles were independently screened by three investigators (AS, ABA and RIPS) in a period of June-July 2021 in two selected databases (PubMed and EBSCO) by using following keywords: a combination of economic evaluation terms ("cost benefit analysis", "cost-effectiveness analysis", "cost utility analysis", "cost minimization analysis", "quality of life", "quality-adjusted life year"), and telemedicine terms ("video", "mobile", "mobile health", "telemedicine", "telemonitoring", "internet", "information technology"). The framework of patient, intervention, comparison, and outcome (PICO) was applied by considering Asian population, the intervention of telemedicine, current situation (without telemedicine) as the comparator, and cost per QALY gained as the major outcome. ${ }^{10}$ Discrepancies were dealt with by consensus or by discussions with other investigators (WS and AAS).

A scoping search was conducted by applying PRISMA flow diagram to identify telemedicine interventions in the disease management. In this study, we applied several inclusion and exclusion criteria. We included studies reported complete economic evaluations, such as costeffectiveness analyses (CEA), cost-utility analyses (CUA), cost-minimization analyses (CMA), and cost-benefit analyses (CBA) by making comparison between telemedicine as the new intervention and without telemedicine as the current intervention. Furthermore, we included complete economic studies that were focused in Asian countries and published in the last ten years (20112021). We specifically excluded studies that were not published in English, not conducted in Asian countries, classified as non-original research articles (eg, systematic reviews, reviews, and meta-analysis), and only available in abstracts and conference proceedings.

To analyze the quality of reporting from each included study, we extracted data by using a predetermined standardized data extraction form, which was approved by all authors and amended as required. We extracted data regarding general study characteristics (eg, author, year of publication, setting and location, study objective, type of study, data collection and analytical method), and other specific methodological characteristics (eg, study perspective, comparison, time horizon, discount rate, choice of model, and parameters in the sensitivity analysis). If a study did not specify the year of currency and cost, we assumed it was the same as the publication year.

\section{Result}

\section{Literature Search}

A total of 870 articles were identified from two databases: PubMed ( $\mathrm{n}=689$ articles) and EBSCO $(\mathrm{n}=181$ articles $)$. After removing 181 duplicates, 689 articles were screened by title and abstract, excluding 665 records. After the fulltext screening on 24 articles, 8 articles were selected for further analysis. More detailed information about PRISMA flow diagram of the study selection can be seen in Figure 1.

\section{General Characteristics}

We derived eight selected studies from five different countries, such as India $(n=3)$, China $(n=1)$, Singapore ( $=2)$, Japan $(\mathrm{n}=1)$, and Thailand $(\mathrm{n}=1) .{ }^{11-18}$ All selected studies compared the intervention of telemedicine with regular interventions that have generally been used in healthcare facilities. Information about the general characteristics of the included studies can be seen in Table 1 .

From three studies that were conducted in India, a study by Rachapelle et al highlighted the cost utility of telemedicine to screen for diabetic retinopathy in Rural Tamil Nadu, Southern India. ${ }^{11}$ Other studies focused on mobile health and telephone-based interventions. A cluster randomized controlled trial study by Modi et al investigated the cost-effectiveness of a mobile health intervention in improving infant mortality to be implemented in Tribal Areas of Gujarat, India. ${ }^{14}$ Another study by Arora et al explored the cost-effectiveness of telephone-based 


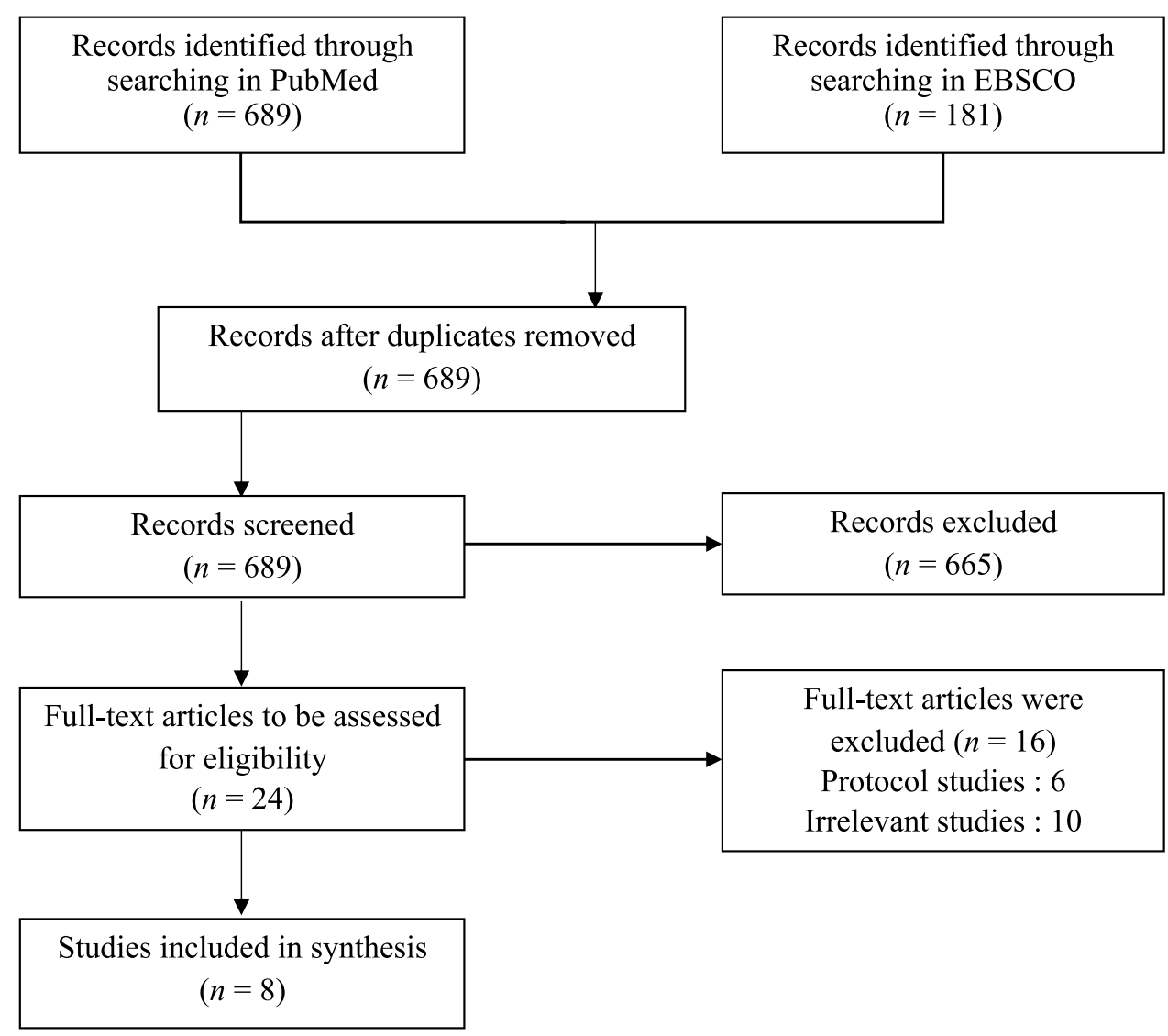

Figure I A flow diagram of study selection.

Notes: From Annals of Internal Medicine, Tricco AC, Lillie E, Zarin W, et al. PRISMA Extension for Scoping Reviews (PRISMA-ScR): Checklist and Explanation. 20I8; 169(7):467-473, Copyright@ [2018] American College of Physicians. All Rights Reserved. Adapted with permission of American College of Physicians, Inc. ${ }^{29}$

intervention to support the management of pressure ulcers in people with spinal cord injury in India and Bangladesh. $^{18}$

From two studies that were conducted in Singapore, a study by Kaur et al in 2020 estimated the costeffectiveness of using hearing aid (HA) plus aural rehabilitation versus delayed hearing aid in adults with hearing impairment. ${ }^{15}$ Applying the urban setting in Singapore, Nguyen et al determined the incremental costeffectiveness of a new telemedicine technician-based evaluation relative to a regular family physician (FP)-based evaluation of diabetic retinopathy (DR) from the perspectives of healthcare and societal. ${ }^{17}$

A study by Song and Kanaoka in Japan specifically investigated the effectiveness of mobile application for menstrual management ini Japanese working women through a randomized controlled trial that was coupled with a medical economic evaluation. ${ }^{12}$ An economic evaluation study to evaluate the differential benefits of home visits with telephone calls and telephone calls only in
Hong Kong, China was conducted by Wong et al in 2015. ${ }^{13}$ Additionally, a study by Kitwitee et al in Thailand applied cost-utility analysis to evaluate the implementation of video-electroencephalography (VEEG) monitoring followed by surgery in adults with drugresistant focal epilepsy. ${ }^{16}$

\section{Methodological Characteristics}

In economic evaluation studies, the choice of perspective is crucial since it affects the cost component to be considered in the study. ${ }^{19}$ Various perspectives were applied in the included studies, such as societal $(n=4)$, societal and healthcare $(n=3)$, and program perspective $(n=1)$. Furthermore, the results of economic evaluation studies are related to the application of time horizon. All studies applied different time horizons. We found two studies applied a 25-year time horizon, ${ }^{11,12}$ and three other studies applied different time horizon, such as 3-month, ${ }^{18} 40$ year, ${ }^{16}$ and lifetime. ${ }^{17}$ The rest of the studies $(n=3)$ did not confirm a time horizon. If studies applied the time 
Table I General Characteristics of Included Studies

\begin{tabular}{|c|c|c|c|c|}
\hline Study & Title & $\begin{array}{l}\text { Setting and } \\
\text { Location }\end{array}$ & Study Objective & $\begin{array}{l}\text { Data Collection and Analytical } \\
\text { Method }\end{array}$ \\
\hline $\begin{array}{l}\text { Rachapelle } \\
\text { et al } \\
\text { India, } 2013 .\end{array}$ & $\begin{array}{l}\text { The cost-utility of telemedicine to } \\
\text { screen for DR in India. }\end{array}$ & $\begin{array}{l}\text { Rural Tamil } \\
\text { Nadu, } \\
\text { Southern } \\
\text { India. }\end{array}$ & $\begin{array}{l}\text { To analyze the cost-effectiveness of } \\
\text { a telemedicine screening program } \\
\text { for diabetic DR in rural Southern } \\
\text { India within different screening } \\
\text { intervals. }\end{array}$ & $\begin{array}{l}\text { - The cost-effectiveness analysis was } \\
\text { based on direct (travel, food, } \\
\text { accommodation, hospital fees and } \\
\text { medicines) and indirect cost (paid } \\
\text { work). } \\
\text { - CEAC was used to characterize } \\
\text { the uncertainty in cost- } \\
\text { effectiveness analysis and applied to } \\
\text { define WTP acceptance ranges. } \\
\text { - Total societal cost of tele- } \\
\text { screening was the sum of health } \\
\text { provider and household } \\
\text { expenditures, and total healthcare } \\
\text { cost was the sum of household } \\
\text { direct and indirect costs minus the } \\
\text { provider costs. }\end{array}$ \\
\hline $\begin{array}{l}\text { Song and } \\
\text { Kanaoka }{ }^{12} \\
\text { Japan, } \\
2018 .\end{array}$ & $\begin{array}{l}\text { Effectiveness of mobile application } \\
\text { for menstrual management of } \\
\text { working women in Japan: RCT and } \\
\text { medical economic evaluation. }\end{array}$ & $\begin{array}{l}\text { Japanese } \\
\text { working } \\
\text { women. }\end{array}$ & $\begin{array}{l}\text { To analyze the cost- effectiveness of } \\
\text { mobile application for menstrual } \\
\text { management in Japanese employed } \\
\text { women. }\end{array}$ & $\begin{array}{l}\text { - The total cost was equal to } \\
\text { application fee, medical services, and } \\
\text { productivity loss. } \\
\text { - The effectiveness of the } \\
\text { application was the reduction of } \\
\text { dysmenorrhea incidence and } \\
\text { depression after three months of } \\
\text { using the application. } \\
\text { - Two scenarios in the sensitivity } \\
\text { analysis were application fee would } \\
\text { increase } 20 \% \text { and incidence of } \\
\text { dysmenorrhea and depression would } \\
\text { decrease } 20 \% \text {. }\end{array}$ \\
\hline $\begin{array}{l}\text { Wong } \\
\text { et al }{ }^{13} \\
\text { China, } \\
2015 .\end{array}$ & $\begin{array}{l}\text { Economic evaluation of the } \\
\text { differential benefits of home visits } \\
\text { with telephone calls and telephone } \\
\text { calls only in transitional discharge } \\
\text { support. }\end{array}$ & $\begin{array}{l}\text { Regional } \\
\text { acute } \\
\text { hospital in } \\
\text { Hong Kong. }\end{array}$ & $\begin{array}{l}\text { To inspect the difference between } \\
\text { home visit plus telephone calls and } \\
\text { telephone calls only in chronic } \\
\text { disease patients after discharging } \\
\text { from hospital. }\end{array}$ & $\begin{array}{l}\text { - Costs and QALYs were calculated } \\
\text { after } 28 \text { and } 84 \text { days of intervention } \\
\text { and comparison was applied } \\
\text { between two groups. } \\
\text { - ICERs were calculated by dividing } \\
\text { differences in costs with differences } \\
\text { in QALYs. } \\
\text { - Multiple imputations by chained } \\
\text { equation methods were used to } \\
\text { input variables, such as gender, age, } \\
\text { activities of daily living score, and the } \\
\text { missing QoL observations. }\end{array}$ \\
\hline
\end{tabular}

(Continued) 
Table I (Continued).

\begin{tabular}{|c|c|c|c|c|}
\hline Study & Title & $\begin{array}{l}\text { Setting and } \\
\text { Location }\end{array}$ & Study Objective & $\begin{array}{l}\text { Data Collection and Analytical } \\
\text { Method }\end{array}$ \\
\hline $\begin{array}{l}\text { Modi } \\
\text { et al }{ }^{14} \\
\text { India, } 2020 \text {. }\end{array}$ & $\begin{array}{l}\text { Costing and cost-effectiveness of } \\
\text { a mobile health intervention in } \\
\text { improving infant mortality in tribal } \\
\text { areas of Gujarat, India: Cluster } \\
\text { RCT. }\end{array}$ & $\begin{array}{l}\text { Tribal and } \\
\text { rural } \\
\text { communities } \\
\text { of Gujarat, } \\
\text { India. }\end{array}$ & $\begin{array}{l}\text { To evaluate how much a mobile } \\
\text { health intervention could save the } \\
\text { incremental cost per life-years when } \\
\text { compared with usual maternal, } \\
\text { neonatal, and child health care } \\
\text { programs. }\end{array}$ & $\begin{array}{l}\text { - ICERs were calculated by dividing } \\
\text { incremental cost of the intervention } \\
\text { with the number of infant deaths } \\
\text { averted. } \\
\text { - Study was analyzed with ITT and } \\
\text { PP. } \\
\text { - ITT implied all live births while PP } \\
\text { would exclude women and infants } \\
\text { who leave the maternal home up to } \\
3 \text { months. }\end{array}$ \\
\hline $\begin{array}{l}\text { Kaur } \\
\text { et al } \\
\text { Singapore, } \\
2020 .\end{array}$ & $\begin{array}{l}\text { Cost-utility analysis of hearing aid } \\
\text { device for older adults in the } \\
\text { community: A delayed start study. }\end{array}$ & Singapore. & $\begin{array}{l}\text { To examine cost-effectiveness of } \\
\text { using hearing aid plus aural } \\
\text { rehabilitation versus delayed hearing } \\
\text { aid in adults with hearing } \\
\text { impairment. }\end{array}$ & $\begin{array}{l}\text { - Patients' utility were measured } \\
\text { with QALY metric and calculated as } \\
\text { a combination of health-related QoL } \\
\text { and duration of life. } \\
\text { - ICER at }<\$ 50.000 \text { was considered } \\
\text { to be cost-effective. }\end{array}$ \\
\hline $\begin{array}{l}\text { Kitwitee } \\
\text { et al } \\
\text { Thailand, } \\
2017 .\end{array}$ & $\begin{array}{l}\text { Cost-utility of VEEG monitoring } \\
\text { followed by surgery in adults with } \\
\text { drug-resistant focal epilepsy in } \\
\text { Thailand. }\end{array}$ & $\begin{array}{l}\text { Specialized } \\
\text { hospital in } \\
\text { Thailand. }\end{array}$ & $\begin{array}{l}\text { To examine cost-effectiveness of } \\
\text { using the VEEG monitoring before } \\
\text { surgery versus medical treatment } \\
\text { without VEEG intervention in } \\
\text { patients with drug-resistant focal } \\
\text { epilepsy under Thai healthcare } \\
\text { context. }\end{array}$ & $\begin{array}{l}\text { - Surgical outcomes were collected } \\
\text { after I- and 2-year post-surgery. } \\
\text { - Effectiveness was measured by life } \\
\text { years and QALYs. } \\
\text { - Non-healthcare cost was collected } \\
\text { from the standard cost list for } \\
\text { Health Technology Assessment in } \\
\text { Thailand. }\end{array}$ \\
\hline $\begin{array}{l}\text { Nguyen } \\
\text { et al }{ }^{17} \\
\text { Singapore, } \\
2016 .\end{array}$ & $\begin{array}{l}\text { Cost-effectiveness of a national } \\
\text { telemedicine DR screening } \\
\text { program in Singapore. }\end{array}$ & $\begin{array}{l}\text { Urban setting } \\
\text { in Singapore. }\end{array}$ & $\begin{array}{l}\text { To determine the incremental cost- } \\
\text { effectiveness of SiDRP in } \\
\text { a comparison with a regular FP- } \\
\text { based evaluation in Singapore from } \\
\text { health system and societal } \\
\text { perspectives. }\end{array}$ & $\begin{array}{l}\text { - Cost was estimated from } \\
\text { healthcare system (medical cost) and } \\
\text { societal perspectives (direct medical, } \\
\text { direct non-medical and indirect } \\
\text { costs). } \\
\text { - Cost-effectiveness between SiDRP } \\
\text { and FP was calculated by considering } \\
\text { cost-effectiveness threshold at } \\
€ 30,000 \text { or SGD63,000 per QALY } \\
\text { gained. }\end{array}$ \\
\hline $\begin{array}{l}\text { Arora } \\
\text { et al }{ }^{18} \\
\text { India, } 2017 .\end{array}$ & $\begin{array}{l}\text { Cost-effectiveness analysis of } \\
\text { telephone-based support for the } \\
\text { management of pressure ulcers in } \\
\text { people with spinal cord injury in } \\
\text { India and Bangladesh. }\end{array}$ & $\begin{array}{l}\text { Three sites in } \\
\text { India and } \\
\text { Bangladesh. }\end{array}$ & $\begin{array}{l}\text { To find out the cost-effectiveness } \\
\text { and cost-utility of management of } \\
\text { pressure ulcers by telephone-based } \\
\text { support from a societal perspective. }\end{array}$ & $\begin{array}{l}\text { - The mean between groups were } \\
\text { calculated by considering the } \\
\text { baseline and follow-up size } \\
\text { differences in pressure ulcer and } \\
\text { using bootstrapping techniques. } \\
\text { - ICER was calculated by } \\
\text { considering every pressure ulcer size } \\
\text { and QALYs gained. }\end{array}$ \\
\hline
\end{tabular}

Abbreviations: CEAC, cost-effectiveness acceptability curve; DR, diabetic retinopathy; FP, family physician; ICER, incremental cost-effectiveness ratio; ITT, intention to treat; PP, pre-protocol; QALYs, quality-adjusted life years; QoL, quality of life; RCT, randomized controlled trial; SiDRP, Singapore Integrated Diabetic Retinopathy Program; VEEG, video-electroencephalography; WTP, willingness to pay. 
horizon more than a year, then the health effect should be modified with a discount rate. We found that four studies applied a discount rate at $3 \%,{ }^{11,14,16,17}$ and one study applied a discount rate at $2 \% .^{12}$

Among all included studies, six studies applied mathematical modeling. ${ }^{11,14-18}$ Rachapelle et al used a Markov model to measure the cost-utility by comparing 6 different screening intervals on 1000 rural diabetic patients, who were 40 years of age and had not previously been screened for DR. ${ }^{11}$ A study by Kitwitee et al also used a Markov model to measure total cost and effectiveness. ${ }^{16}$ In addition, a study by Kaur et al used Markov model to assess cost effectiveness in using HA, compared with non-HA group. ${ }^{15}$ Modi et al considered relevant cost and effectiveness parameters in the implementation of mobile health intervention within a decision tree model. ${ }^{14}$ Wong et al applied a randomized control trial to explore readmission outcome by comparing home visit plus phone calls with phone calls only for patients discharged from medical unit due to chronic illness. ${ }^{13}$

Furthermore, Arora et al used a Markov model to calculate the incremental cost-effectiveness ratio (ICER) in a comparison between telemedicine-based DR screening and FP-based DR screening over a lifetime. ${ }^{18}$ A Markov model was also applied by Nguyen et al to estimate the cost-effectiveness of telemedicine by considering two major factors: (i) if telemedicine was less cost and higher utility, compared with regular model, telemedicine would be cost-saving; and (ii) if telemedicine was more expensive and higher utility, compared with regular model, ICER will be the difference in total costs divided by the difference in total QALYs gained. ${ }^{17}$

Additionally, sensitivity analysis is necessary to be included in economic evaluation studies to assess the impact of uncertain parameters in the ICER. From all retrieved studies, only two studies did not apply sensitivity analysis. $^{13,16}$ Other studies $(\mathrm{n}=6)$ applied sensitivity analysis by considering various parameters, such as prevalence of the disease, intervention cost (eg, direct medical, direct non-medical, indirect, and other relevant costs), utility, disease degree, and other outcomes. More detailed information about the methodological characteristics of the included studies can be seen in Table 2 .

\section{Discussion}

In this study, we reviewed eight articles that focused on investigating the cost-effectiveness of telemedicine in Asia. $^{11-18}$ Two studies by Arora et al and Wong et al specifically investigated the cost-effectiveness of mobile phone intervention in India and Bangladesh; and Hong Kong, respectively. Comparing telephone-based support with usual care in management of pressure ulcers in 120 people with spinal cord injury in India and Bangladesh, a study by Arora et al concluded the probability of the intervention to be cost-effective would be $41 \%{ }^{18}$ In the context of reducing the hospital readmissions, a study by Wong et al confirmed that the intervention of home visit and calls was more effective than calls only. ${ }^{13}$ In particular, two other studies focused on the costeffectiveness of mobile health application. Focusing on the use of m-Health program for maternal, neonatal, and child healthcare management in Gujarat, India, a study by Modi et al concluded that the intervention was cost-effective and recommended to be implemented in a wider range of population in India. ${ }^{14}$ Comparing the use of mobile application versus not using mobile application in female workers for menstrual management in Japan, a study by Song and Kanaoka highlighted the intervention group resulted QALYs and costs at 0.07 higher and \$1170 lower than the control group, respectively. ${ }^{12}$

Considering the implementation of FP and Singapore Integrated Diabetic Retinopathy Program (SiDRP), a study by Nguyen et al concluded SiDRP as the new intervention showed better cost-effectiveness value than FP in the context of DR screening program. ${ }^{17}$ Another similar study by Rachapelle et al in 2018 also highlighted that teleophthalmology screening program was considered to be more cost-effective than no DR screening in rural Tamil Nadu, Southern India. ${ }^{11}$ In the context of video monitoring, a study by Kitwitee et al in Thailand confirmed the probability of VEEG to be cost-effective was $84 \%$ by applying a cost-effective threshold at THB 160,000 per QALY gain. ${ }^{16}$ Taking the use of $\mathrm{HA}$ as a telemedicine, a study by Kaur et al confirmed that HA as a telemedicine could be cost-effective in a person with hearing-impairment after a short period of using the device and long-term costeffectiveness of HA would depend on the duration of use of intervention. ${ }^{15}$ More detailed information about the primary results of all included studies can be seen in Table 3.

All of these included studies have proven that the use of telemedicine was more cost-effective than the traditional programs by increasing therapeutic effects and providing improvement in the efficiency of health services. $^{20}$ It can be highlighted that telemedicine is a promising approach to increase life expectancy and 
Table 2 Methodological Characteristics of Included Studies

\begin{tabular}{|c|c|c|c|c|c|c|}
\hline Study & $\begin{array}{c}\text { Study } \\
\text { Perspective }\end{array}$ & Comparison & $\begin{array}{c}\text { Time } \\
\text { Horizon }\end{array}$ & $\begin{array}{l}\text { Discount } \\
\text { Rate (\%) }\end{array}$ & $\begin{array}{l}\text { Choice } \\
\text { of Model }\end{array}$ & $\begin{array}{c}\text { Parameter in the Sensitivity } \\
\text { Analysis }\end{array}$ \\
\hline $\begin{array}{l}\text { Rachapelle } \\
\text { et al } \\
\text { India, } 2013 .\end{array}$ & $\begin{array}{l}\text { Societal and } \\
\text { healthcare }\end{array}$ & $\begin{array}{l}\text { Teleophthalmology vs regular } \\
\text { screening }\end{array}$ & 25 years & 3 & $\begin{array}{l}\text { Markov } \\
\text { model }\end{array}$ & $\begin{array}{l}\text { Utility values, bilateral blindness } \\
\text { from DR, annual transition } \\
\text { probabilities, prevalence of DR } \\
\text { among diabetic, proportion of } \\
\text { patients misdiagnosed by retinal } \\
\text { camera, mortality multipliers, and } \\
\text { probability of attending for } \\
\text { treatment after referral. }\end{array}$ \\
\hline $\begin{array}{l}\text { Song and } \\
\text { Kanaoka }{ }^{12} \\
\text { Japan, } \\
2018 .\end{array}$ & Societal & Mobile application vs control group & 25 years & 2 & RCT & $\begin{array}{l}\text { Incidence, application fee, medical } \\
\text { expense, labor productivity, total } \\
\text { cost, and QALYs. }\end{array}$ \\
\hline $\begin{array}{l}\text { Wong } \\
\text { et al } \\
\text { China, } \\
2015 \text {. }\end{array}$ & Societal & Home visit with calls vs calls only & - & - & RCT & - \\
\hline $\begin{array}{l}\text { Modi } \\
\text { et } \text { al }^{14} \\
\text { India, } 2020 \text {. }\end{array}$ & Program & $\begin{array}{l}\text { Mobile health intervention vs } \\
\text { current maternal, neonatal, and } \\
\text { child health services }\end{array}$ & - & 3 & $\begin{array}{l}\text { Decision } \\
\text { tree }\end{array}$ & $\begin{array}{l}\text { Infant deaths averted, cost, cost per } \\
\text { infant death averted, and cost per } \\
\text { life year. }\end{array}$ \\
\hline $\begin{array}{l}\text { Kaur } \\
\text { et al } \\
\text { Singapore, } \\
2020 \text {. }\end{array}$ & Societal & VEEG vs treatment without VEEG & - & - & $\begin{array}{l}\text { Markov } \\
\text { model }\end{array}$ & $\begin{array}{l}\text { Proportion of patients receiving } \\
\text { surgery, surgical death, transient } \\
\text { complication, permanent } \\
\text { complication, seizure outcomes } \\
\text { after surgery, seizure outcomes of } \\
\text { medical treatment, sensorimotor } \\
\text { rhythm, cost, and utility. }\end{array}$ \\
\hline $\begin{array}{l}\text { Kitwitee } \\
\text { et al } \\
\text { Thailand, } \\
2017 .\end{array}$ & $\begin{array}{l}\text { Societal and } \\
\text { healthcare }\end{array}$ & $\begin{array}{l}\text { The fitted group (the one that used } \\
\text { HA immediately added with short- } \\
\text { term post audiological } \\
\text { rehabilitation) vs the control group } \\
\text { (the one that used HA three } \\
\text { months later). }\end{array}$ & 40 years & 3 & $\begin{array}{l}\text { Markov } \\
\text { model }\end{array}$ & - \\
\hline $\begin{array}{l}\text { Nguyen } \\
\text { et al }{ }^{17} \\
\text { Singapore, } \\
2016 .\end{array}$ & $\begin{array}{l}\text { Societal and } \\
\text { healthcare }\end{array}$ & Telemedicine vs regular screening & Lifetime & 3 & $\begin{array}{l}\text { Markov } \\
\text { model }\end{array}$ & $\begin{array}{l}\text { Prevalence of DR, specificity, DR } \\
\text { transition probabilities, cost items, } \\
\text { and utility. }\end{array}$ \\
\hline $\begin{array}{l}\text { Arora } \\
\text { et } \mathrm{al}^{18} \\
\text { India, } 2017 .\end{array}$ & Societal & $\begin{array}{l}\text { Telephone-based support vs regular } \\
\text { care }\end{array}$ & 3 months & - & $\begin{array}{l}\text { Linear } \\
\text { regression }\end{array}$ & $\begin{array}{l}\text { Cost, reduction in pressure ulcer } \\
\text { size }\left(\mathrm{cm}^{2}\right) \text {, average utility score } \\
\text { over } 12 \text { weeks, and incremental } \\
\text { QALYs. }\end{array}$ \\
\hline
\end{tabular}

Abbreviations: DR, diabetic retinopathy; HA, hearing aid; RCT, randomized controlled trial; VEEG, video-electroencephalography; QALYs, quality-adjusted life years.

to reduce infant mortality. ${ }^{14,16}$ It can also increase the effectiveness of treatment. ${ }^{18}$ In addition, the potential of telemedicine to be a cost-saving intervention has been confirmed by the evidence in a study by Nguyen et al, ${ }^{17}$ which strengthened the results of a previous study by $\mathrm{Ji}$ et al in terms of telemedicine can save patients' time and travel costs. ${ }^{21}$

In the context of Sustainable Development Goals (SDGs), the United Nations has committed the SDGs to be achieved by 2030 with the 3 rd SDG is to ensure healthy 
Table 3 Primary Results

\begin{tabular}{|c|c|}
\hline Study & Main Conclusion \\
\hline $\begin{array}{l}\text { Rachapelle et al }{ }^{11} \text { India, } \\
2013 .\end{array}$ & $\begin{array}{l}\text { Applying a health provider perspective, teleophthalmology screening for DR is cost-effective compared with no } \\
\text { screening in rural Indian setting. The results are dependent on the administrative costs (eg, for establishing and } \\
\text { maintaining screening at regular intervals) and program coverage. }\end{array}$ \\
\hline $\begin{array}{l}\text { Song and Kanaoka }{ }^{12} \\
\text { Japan, } 2018 .\end{array}$ & $\begin{array}{l}\text { The aggregate of medical expenses, productivity loss, and application fee for the intervention group was reported to } \\
\text { be lower ( } \$ 1170 \text { per individual) than for the non-intervention group. The results conclude that using the application is } \\
\text { cost-effective and might reduce the incidence of dysmenorrhea and depression. }\end{array}$ \\
\hline Wong et $\mathrm{al}^{13}$ China, 20I5. & $\begin{array}{l}\text { Both of home visits and calls only are cost-effective for transitional care support, but calls only have a higher chance of } \\
\text { being cost-effective for a sustained period after intervention in patients with chronic illness. }\end{array}$ \\
\hline Modi et al $^{14}$ India, 2020. & $\begin{array}{l}\text { A mobile health intervention is cost-effective from a program perspective at an incremental cost of } \$ 74 \text { per life-years } \\
\text { saved. Considering district scale-up, the program is even more cost-effective. Hence, the program is recommended for } \\
\text { replication elsewhere in India. }\end{array}$ \\
\hline $\begin{array}{l}\text { Kaur et al }{ }^{15} \text { Singapore, } \\
2020 .\end{array}$ & $\begin{array}{l}\text { HA intervention can be cost-effective and improve the QoL of hearing-impaired older individuals within a brief period } \\
\text { of device fitting. Its continued usage would impact the long-term cost-effectiveness value. }\end{array}$ \\
\hline $\begin{array}{l}\text { Kitwitee et } \text { al }^{16} \text { Thailand, } \\
2017 .\end{array}$ & $\begin{array}{l}\text { VEEG was considered to be cost-effective for patients with drug-resistant epilepsy. Therefore, in Thailand, it is } \\
\text { recommended to be included in the benefit package of health insurance. }\end{array}$ \\
\hline $\begin{array}{l}\text { Nguyen et al }{ }^{17} \text { Singapore, } \\
2016 .\end{array}$ & $\begin{array}{l}\text { In Singapore, telemedicine-based DR screening using technicians in the primary care setting is cost saving, compared } \\
\text { with the FP-based evaluation. }\end{array}$ \\
\hline Arora et al ${ }^{18}$ India, 2017. & $\begin{array}{l}\text { In the context of QALYs, telephone-based support could help people to manage pressure ulcers at home by providing } \\
\text { good value for money with an } 87 \% \text { probability of being cost-effective, according to } 3 \text { times gross domestic product. } \\
\text { The inclusion of productivity costs in sensitivity analyses did not alter this finding. }\end{array}$ \\
\hline
\end{tabular}

Abbreviations: DR, diabetic retinopathy; FP, family physician; HA, hearing aid; RCT, randomized controlled trial; VEEG, video-electroencephalography; QALYs, qualityadjusted life years; QoL, quality of life.

living and promote well-being for all people at all ages. ${ }^{22}$ It can be highlighted that all human beings have the same rights to access good health service that will support sustainable development and socioeconomic improvements. As an alternative choice, telemedicine can be used for people with limited access to direct health services. In low-income countries, it can be an alternative for patients who cannot afford good healthcare services that are not covered by the social insurance. For health crisis mitigation, the use of telemedicine can also be optimized because of its cost-effectiveness. ${ }^{1}$

In Asia, telemedicine has become popular and has been used to expand more access to essential health services, specifically for rural communities who have barriers to getting accessible healthcare facilities because they are concentrated in urban areas. Other problems that patients from rural areas may face are poor infrastructures and complicated geographic locations. In this case, telemedicine has the ability to deliver healthcare services, provide better information, decrease discrepancies in the healthcare, and improve healthcare outcomes. ${ }^{23,24}$ In particular, telemedicine can assist the healthcare system to be more patient-centered. ${ }^{25}$ Because of the increasing number of smartphones' users, the extensive use of internet, and the application of electronic medical records, the possibility of telemedicine to be included in the healthcare system is getting higher. ${ }^{26}$ Nevertheless, the illiteracy of technology and the unaffordability of supporting devices remain the biggest challenges in the implementation of telemedicine in low-income countries. ${ }^{27,28}$

To our knowledge, this study is the first scoping review study that focused on the economic evaluations of telemedicine in Asia. Despite the fact that this study has a major novelty, it also has several limitations. First, we were unable to conduct a meta-analysis due to heterogeneity of the included studies. Nevertheless, we have provided a narrative review by outlining the current evidence on this topic and highlighting gap that remains unexplored for future studies. Secondly, we found the risk of publication bias since we only focused on peer-reviewed published studies to ensure comparable study quality. Nevertheless, this study provides an overview about the potential costeffectiveness of telemedicine in health services to improve patients' quality of life as the final outcome. Hopefully, 
this study can assist the stakeholders in making decisions regarding the implementation of telemedicine in Asia.

\section{Conclusions}

The results suggest that the implementation of telemedicine in Asia can be a promising intervention since it can enhance the effectiveness of health services by saving time and travel costs. It also can reduce the overall costs of treatment, improve patients' quality of life and expand access to essential health services.

\section{Disclosure}

The authors report no conflicts of interest in this work.

\section{References}

1. Kichloo A, Albosta M, Dettloff K, et al. Telemedicine, the current COVID-19 pandemic and the future: a narrative review and perspectives moving forward in the USA. Fam Med Com Health. 2020;8(3): e000530. doi:10.1136/fmch-2020-000530

2. Smith AC, Thomas E, Snoswell CL, et al. Telehealth for global emergencies: implications for coronavirus disease 2019 (COVID-19). J Telemed Telecare. 2020;26(5):309-313. doi:10.1177/ 1357633X20916567

3. Suzuki T, Hotta J, Kuwabara T, et al. Possibility of introducing telemedicine services in Asian and African countries. Health Policy Technol. 2020;9(1):13-22. doi:10.1016/j.hlpt.2020.01.006

4. Peddle K. Telehealth in context: socio-technical barriers to Telehealth use in Labrador, Canada. Comput Supported Coop Work. 2007;16 (6):595-614. doi:10.1007/s10606-006-9030-3

5. Ekeland AG, Bowes A, Flottorp S. Effectiveness of telemedicine: a systematic review of reviews. Int $J$ Med Inform. 2010;79 (11):736-771. doi:10.1016/j.ijmedinf.2010.08.006

6. Green T, Hartley N, Gillespie N. Service provider's experiences of service separation: the case of telehealth. J Serv Res. 2016;19 (4):477-494. doi:10.1177/1094670516666674

7. Edirippulige S, Brooks P, Carati C, et al. It's important, but not important enough: eHealth as a curriculum priority in medical education in Australia. J Telemed Telecare. 2018;24(10):697-702. doi:10.1177/1357633X18793282

8. Bhaskar S, Bradley S, Chattu VK, et al. Telemedicine as the new outpatient clinic gone digital: position paper from the pandemic health system REsilience PROGRAM (REPROGRAM) international consortium (Part 2). Front Public Health. 2020;8:410. doi:10.3389/ fpubh.2020.00410

9. Bergmo TS. Using QALYs in telehealth evaluations: a systematic review of methodology and transparency. BMC Health Serv Res. 2014;14(1):332. doi:10.1186/1472-6963-14-332

10. Eriksen MB, Frandsen TF. The impact of patient, intervention, comparison, outcome (PICO) as a search strategy tool on literature search quality: a systematic review. jmla. 2018;106:4. doi:10.5195/JMLA.2018.345

11. Rachapelle S, Legood R, Alavi Y, et al. The cost-utility of telemedicine to screen for diabetic retinopathy in India. Ophthalmology. 2013;120(3):566-573. doi:10.1016/j.ophtha.2012.09.002

12. Song M, Kanaoka H. Effectiveness of mobile application for menstrual management of working women in Japan: randomized controlled trial and medical economic evaluation. J Med Econ. 2018;21 (11):1131-1138. doi:10.1080/13696998.2018.1515082
13. Wong FKY, So C, Chau J, Law AKP, Tam SKF, McGhee S. Economic evaluation of the differential benefits of home visits with telephone calls and telephone calls only in transitional discharge support. Age Ageing. 2015;44(1):143-147. doi:10.1093/ageing/afu166

14. Modi D, Saha S, Vaghela P, et al. Costing and cost-effectiveness of a mobile health intervention (ImTeCHO) in improving infant mortality in tribal areas of Gujarat, India: cluster randomized controlled trial. JMIR Mhealth Uhealth. 2020;8(10):e17066. doi:10.2196/17066

15. Kaur P, Chong SL, Kannapiran P, et al. Cost-utility analysis of hearing aid device for older adults in the community: a delayed start study. BMC Health Serv Res. 2020;20(1):1112. doi:10.1186/ s12913-020-05977-x

16. Kitwitee P, Unnwongse K, Srikijvilaikul T, Yadee T, Limwattananon C. Cost-utility of video-electroencephalography monitoring followed by surgery in adults with drug-resistant focal epilepsy in Thailand. World Neurosurg. 2017;98(750-760.e3):750760.e3. doi:10.1016/j.wneu.2016.11.041

17. Nguyen HV, Tan GSW, Tapp RJ, et al. Cost-effectiveness of a national telemedicine diabetic retinopathy screening program in Singapore. Ophthalmology. 2016;123(12):2571-2580. doi:10.1016/j. ophtha.2016.08.021

18. Arora M, Harvey LA, Glinsky JV, et al. Cost-effectiveness analysis of telephone-based support for the management of pressure ulcers in people with spinal cord injury in India and Bangladesh. Spinal Cord. 2017;55(12):1071-1078. doi:10.1038/sc.2017.87

19. Indonesian Ministry of Health. Guidelines for the Implementation of Pharmacoeconomics Studies. Directorate General of Pharmaceutical and Medical Devices Development; 2013.

20. Jennett PA, Affleck Hall L, Hailey D, et al. The socio-economic impact of telehealth: a systematic review. $J$ Telemed Telecare. 2003;9(6):311-320. doi:10.1258/135763303771005207

21. Ji X, Wang Y, Ma Y, et al. Improvement of disease management and cost effectiveness in Chinese patients with Ankylosing Spondylitis using a smart-phone management system: a prospective cohort study. Biomed Res Int. 2019;2019:1-11. doi:10.1155/2019/2171475

22. Nunes AR, Lee K, O'Riordan T. The importance of an integrating framework for achieving the sustainable development goals: the example of health and well-being. BMJ Glob Health. 2016;1(3): e000068. doi:10.1136/bmjgh-2016-000068

23. Delaigue S, Bonnardot L, Steichen O, et al. Seven years of telemedicine in Médecins Sans Frontières demonstrate that offering direct specialist expertise in the frontline brings clinical and educational value. J Glob Health. 2018;8(2):020414. doi:10.7189/jogh.08.020414

24. Jha AK, Sawka E, Tiwari B, et al. Telemedicine and community health projects in Asia. Dermatol Clin. 2021;39(1):23-32. doi:10.1016/j.det.2020.08.003

25. Boxer RJ. Advantages and utilization of telemedicine. mHealth. 2019;5:12. doi:10.21037/mhealth.2019.04.02

26. Chellaiyan V, Nirupama A, Taneja N. Telemedicine in India: where do we stand? J Family Med Prim Care. 2019;8(6):1872. doi:10.4103/ jfmpc.jfmpc_264_19

27. Eze ND, Mateus $\bar{C}$, Cravo Oliveira Hashiguchi T. Telemedicine in the OECD: an umbrella review of clinical and cost-effectiveness, patient experience and implementation. PLoS One. 2020;15(8):e0237585. doi:10.1371/journal.pone.0237585

28. Bonnardot L, Wootton E, Liu J, et al. User feedback on the MSF teleexpertise service after a 4-year pilot trial - a comprehensive analysis. Front Public Health. 2015;3. doi:10.3389/fpubh.2015.00257

29. Tricco AC, Lillie E, Zarin W, et al. PRISMA Extension for Scoping Reviews (PRISMA-ScR): Checklist and Explanation. Ann Intern Med. 2018;169(7):467-473. doi:10.7326/M18-0850 


\section{Publish your work in this journal}

The Journal of Multidisciplinary Healthcare is an international, peerreviewed open-access journal that aims to represent and publish research in healthcare areas delivered by practitioners of different disciplines. This includes studies and reviews conducted by multidisciplinary teams as well as research which evaluates the results or conduct of such teams or healthcare processes in general. The journal covers a very wide range of areas and welcomes submissions from practitioners at all levels, from all over the world. The manuscript management system is completely online and includes a very quick and fair peer-review system. Visit http://www.dovepress.com/testimonials. php to read real quotes from published authors. 